WIDER Working Paper 2014/136

\title{
Scoping paper on Kenyan manufacturing
}

Jacob Chege, ${ }^{1}$ Dianah Ngui, ${ }^{2}$ and Peter Kimuyu ${ }^{3}$

October 2014 
Abstract: Three major policy regimes, namely import substitution, market liberalization and export promotion have greatly influenced Kenyan industrialization since independence in 1963. Overall, import substitution strategy was successful in establishing some primary industries but led to reduced domestic competition and low capacity utilization. Market liberalization policies in 1980 failed as local industries were unable to compete with imports. The export orientation strategy in the 1990s was unsuccessful due to poor implementation of fiscal initiatives and macro-economic mismanagement. Reforms since 2003 have stabilized industrial production but challenges remain in infrastructure, energy and market access. The future of Kenyan industry lies in high-value production.

Keywords: industrial policy, productivity, reforms, structure of industry JEL classification: O25, O47, O55, P41

Acknowledgements: This paper is one of a series of studies on industrial development in Africa produced in collaboration between the Africa Growth Initiative at Brookings, the African Development Bank (AfDB), and UNU-WIDER under their joint project 'Learning to Compete' (L2C).

\footnotetext{
${ }^{1}$ Kenya Institute for Public Policy Research and Analysis, Nairobi; ${ }^{2}$ Kenyatta University, Nairobi; ${ }^{3}$ University of Nairobi; corresponding author: jchege@kippra.or.ke

This study has been prepared within the UNU-WIDER project 'Learning to Compete: Accelerating Industrial Development in Africa', (http://www.wider.unu.edu/research/current-programme/en_GB/L2C-2010), directed by John Page.

Copyright (C) AfDB/Brookings/UNU-WIDER 2014

ISSN 1798-7237 ISBN 978-92-9230-857-5

Typescript prepared by Judy Hartley for UNU-WIDER.

UNU-WIDER gratefully acknowledges the financial contributions to the research programme from the governments of Denmark, Finland, Sweden, and the United Kingdom.

The World Institute for Development Economics Research (WIDER) was established by the United Nations University (UNU) as its first research and training centre and started work in Helsinki, Finland in 1985. The Institute undertakes applied research and policy analysis on structural changes affecting the developing and transitional economies, provides a forum for the advocacy of policies leading to robust, equitable and environmentally sustainable growth, and promotes capacity strengthening and training in the field of economic and social policy-making. Work is carried out by staff researchers and visiting scholars in Helsinki and through networks of collaborating scholars and institutions around the world.
}

UNU-WIDER, Katajanokanlaituri 6 B, 00160 Helsinki, Finland, wider.unu.edu

The views expressed in this publication are those of the author(s). Publication does not imply endorsement by the Institute or the United Nations University, nor by the programme/project sponsors, of any of the views expressed. 
This paper seeks to review the history of manufacturing in Kenya over time, starting with the period immediately before independence in 1963. The review discusses industrial policies pursued by different regimes and their impact on Kenyan manufacturing. There is also a discussion of the structure of the industrial sector as well as its contribution to employment and the different sectors' future prospects. A discussion on size distribution and factor productivity structured around ownership, legal status and export participation follows, and the paper concludes with a reflection on factors that have shaped industrial development in Kenya.

Kenya approached independence under conditions of high racial inequalities, unemployment and landlessness among Africans. A state of emergency forced the colonial administration to adjust its agricultural policies by publishing the Swynnerton Plan in 1954. In this plan, new land tenure proposals considered important for further agricultural development, were pronounced. Simultaneously, recommendations made by the then East African Royal Commission made the case for issuance of title deeds to pave the way for progressive farming (Kinyanjui 2013) from which agro-industries and general industrial development would feed. The colonial administration also introduced tariffs in 1958 to prop import substitution, this being an outcome of its policies backed by a push from British industrial concerns operating in Kenya at the time.

Kenya was also pursuing import substitution well before independence. At independence in 1963, the new government found itself under intense pressure to translate political independence into economic emancipation. Realizing the limited local capacity to create significant industrial activity and employment, the government enacted a raft of laws to not only retain but also attract foreign investment. Examples include the Foreign Investment Protection Act in 1964 that allowed foreign investors to repatriate profits and interest on loans. A New Projects Committee was set up in 1968 to fast-track applications by multinational corporations to invest in Kenya. This committee also served as a mechanism for negotiation between the new government and multinational corporations. The Capital Issues Committee was established in 1971 to vet all issues of capital stock. Simultaneously, the government begun to recognize the need to harness indigenous entrepreneurship through the Industrial and Commercial Development Corporation (ICDC) which was tasked to promote the participation of indigenous Kenyans in industrial and commercial activities (Hecox 1988). Further pursuit of this agenda led to the launch of the Kenya Industrial Estates programme in 1967 for the purpose of supporting small local entrepreneurs to increase their capacity to participate in manufacturing. The Trade Licensing Act of 1967 restricted certain types of trade and trading zones to Africans. By this act, non-Africans were prohibited from trading in rural Kenya and peri-urban areas of Kenyan towns. The new government also promoted local industrial production by attempting to reduce the cost of borrowing and therefore spur private sector growth. Both ICDC and the Development Finance Company of Kenya were tasked to offer concessionary credit to all investors with a particular preference for indigenous investors.

A large proportion of foreign direct investment (FDI) during the first independent decade resulted in the establishment of large textile mills such as Rivertex, Kicomi and United Cotton Mills. Other foreign investment went to the production of a range of products with a substantial local market such as dry cells, tyres, light bulbs, confectionery or stainless steel tanks. Other investments went into assembling motor vehicles. Agro-processing was dominated by cotton ginning as cotton growing was an important economic activity dominated by private colonial capital.

In due course, the import substitution strategy precipitated backward integration of textile mills. In response, the government systematically introduced controls into the sector, imposing a 100 per cent duty on imported textiles and fixing producer prices. A programme was mounted through 
which existing ginneries were bought by cooperatives. Nevertheless, dominance of the textile industry in the Kenyan manufacturing sector lasted until the mid-1980s when trade liberation saw the influx of cheap textile goods and secondhand clothes into the Kenyan market. This had a disastrous effect on the sector and led to the near collapse of the local textile industry in the early 1990s. This situation was somewhat ameliorated when, in 2001, the US government enacted the African Growth and Opportunities Act (AGOA) that allowed African countries to export textile and garments duty-free and without import quota restrictions. The rise in exports of garments and apparel from Kenya in the last decade can be attributed to export opportunities in the US fabric market. By this time, food processing had already begun to dominate manufacturing and accounted for a third of total manufacturing output in 2010 (US Commercial Service 2011). Products categorized under food processing include bakery products, grain milling products, vegetable/animal oils and fats, dairy products, canning fruits and vegetables. This sector is dominated by subsidiaries of multinational corporations operating either as foreign companies or as joint ventures with Kenyan shareholdings to supply the domestic and neighbouring markets.

The metal sub-sector also has a long history in Kenya, having been established shortly before independence. Other than production by the informal sector, which attracted the attention of policy makers in the 1970s, the major industrial concerns in the metal sub-sector are owned by Kenyans of Asian origin and include Kenya United Steel Company, Steel Africa, Mabati Rolling Mills, Insteel, Kaluworks, Galsheet and Doshi. Kenya United Steel Ltd. was the pioneer firm, having started as early as 1949. The range of products manufactured by these industries includes nails, galvanized sheets and pipes, and has remained unchanged over the last four decades of their operations in Kenya. These products have largely supported the construction industry and complemented cement production, which has also a long history in Kenya but has been, until recently, dominated by two firms, the Bamburi Portland Cement Company and the East African Portland Cement Company, both having started before independence. More recently, other new cement manufacturing firm, including Devki and Mombasa Cement, have made their debut in the Kenyan industrial scene. There are others on the drawing board, attracted by rapidly expanding construction in Kenya and the rest of East Africa.

Kenya's industrial future is likely to be altered by recent discoveries of iron ore in the eastern part of the country (Ministry of Industrialization and Enterprise Development 2011), the discovery of oil in northern parts of the country (Business Daily 2013) and the devolution and creation of county governments that resulted from the implementation of a new constitution promulgated in 2010.

\section{Evolution of industrial policies since independence}

\subsection{Import substitution hangover 1963-70}

Like many developing countries, Kenya's early years of independence pursued an industrialization strategy that relied on an import substitution (IS) strategy in which the government provided both direct support and tariff protection for the industry. This strategy was a carryover from colonial policies, and its objectives were rapid growth of industry, easing balance of payment pressures, encouraging indigenous participation in the sector, increasing productivity and high-income employment. However, the IS policy failed to create much-needed employment because of its capital-intensive nature. Its high import content also caused major balance of payment problems.

In the end, the import substitution phase and the policies that sustained it had mixed results. On the positive side, the country enjoyed a significantly high rate of industrial growth during the first decade of independence. The manufacturing sector grew at an average rate of 8 per cent and was second only to agriculture in terms of employment creation during this period. Manufacturing 
output grew faster than not only the rest of the Kenyan economy but also other industrial sectors in Sub-Saharan Africa. Industries that recorded rapid development during this period included plastics, pharmaceuticals, steel rolling and galvanizing, electrical cables, paper, vehicle assembly, industrial gases, rubber, ceramics and batteries. Light industries accounted for the lion's share of gross industrial production followed by intermediate industries (Kinyanjui 2013). Some industries expanded from a few establishments into industries with a wide range of products and a large number of employees. These included paper, textiles and garment manufacturing, food processing, leather tanning and footwear (Coughlin 1988; KAM 1988). The IS strategy was successful in establishing industries in textiles and garments, food, beverages and tobacco-industries that are still industries today. The strategy was implemented in an environment of generalized optimism that created a climate supportive of widespread economic performance.

\subsection{Policies during external shocks: The 1970s}

The 1970s were the most turbulent years in Kenya's history and were marked by a general deterioration in the country's overall economic performance. The government of the day chose to deepen its participation in the economy using the strategy of import substitution, promoting and financing new industrial projects. In 1970, it established the Industrial Survey and Promotion Centre which was mandated to systematically promote industrial development. The Capital Issues Committee, vaunted as the single most important instrument of nationalization, was set up in 1971. The Industrial Development Bank was also established in 1973 with the mandate of promoting joint ventures between domestic and foreign capital around import substitution activities. An Export Compensation Manufacturer's Act was also enacted in 1974 to promote non-traditional export products within the framework of import substitution.

Industrial production for export markets slowed down substantially because the incentive structure favoured production for domestic markets, creating an inward-looking industrial sector whose potential was severely limited by the size of the domestic market. The situation was compounded by the collapse of the East African Community (EAC) in 1977. In addition, there was an erosion of fiscal discipline after the coffee boom in the late 1970s, which was aggravated by a deterioration in the country's external terms of trade following the second oil shock in 1977 (Foroutan 1993). The import substitution strategy was in general strongly biased against exports. The limited local demand slowed the IS drive while initial efforts to shift to export promotion were constrained by structural rigidities, low productivity and macroeconomic instability. In addition, the protection strategy reduced competition within the domestic industry, making industries act as monopolies, reaping high profits while operating at low capacity utilization and raising prices to consumers. Industries became inefficient, operating at high costs because of fewer incentives to concentrate on reducing costs and improving the quality of both consumption and intermediate goods. Under these circumstances, Kenyan products could not compete in the export markets. Industries found it more profitable to produce for the highly protected domestic market, resulting in an 'anti-export bias' (GoK 1994). The country has encountered a major foreign exchange crisis, forcing the government to further tighten controls, such as through more exacting import licensing procedures, higher tariffs and generalized price controls (Bigsten, Kimuyu and Söderbom 2010). Such administrative interventions further undermined export incentives, leading to shrinkage in the share of manufacturing exports. Inefficiency in the industrial sector and lack of competitiveness in its products led to a review of the industrial strategy and the structure of incentives. The economy was also battered by a series of external shocks. Introduction of import restrictions through tightening exchange controls and import licensing precipitated deterioration in the terms of trade. There was also an increase in oil prices in 1973/74 causing the import bill to explode. The consequential deterioration in the balance of payments position necessitated tariff and interest rate reforms. There was a positive shock and balance of payment relief following coffee and tea booms in 1976/77, the benefits of which were eroded by increased public spending 
and the collapse of the EAC in 1977. These events were followed by another global oil price shock in 1979. Crisis management led to a ban on some imports towards the end of the 1970s.

Of particular importance to manufacturing in this period was the emergence of the informal sector, supported by official recognition and pro-informal sector policies. The manufacturing outcomes of such policies were, however, eroded by selective implementation that made provision for the exploitation of linkages between the informal sector and other sectors. Overall, the IS strategy penalized certain sectors, such as the agricultural sector, that suffered high input costs. But the government continued to subsidize and guarantee industrial expansion through foreign capital in ways that made it possible for African industrialists to penetrate large-scale manufacturing (Kinyanjui 2013).

\subsection{Structural adjustment and liberalization: The 1980s and 1990s}

During the 1980s, the government introduced structural adjustment programmes (SAP) in order to, inter alia, strengthen competitiveness and reduce excess capacity in the industrial sector to address concerns raised about distortions caused by the IS strategy. These included virtual removal of price controls and liberalization of imports through the removal of import and foreign exchange licensing and rationalized tariff regimes (Gerdin 1997). A major restructuring of policies and the institutional framework was also initiated through the publication of a session paper on Economic Management for Renewed Growth (Republic of Kenya 1986). The policy measures in this paper were aimed at removing the 'anti-export bias' inherent in previous policies. The government also undertook to completely remove restrictive import licensing and tariffs. In 1993, import licensing schedules were abolished and capital and current transactions were fully liberalized in 1994 with the removal of all price controls. In the same year, Kenya joined the World Trade Organization (WTO) and the Kenyan economy was declared 'open'.

We can therefore conclude that the SAPs led to liberalization of the domestic economy-for both output and input markets - and opened it to international competition (Chirwa 2000). However, the industrial sector continued to be inward-oriented, excessively import-dependent, capitalintensive and incapable of absorbing an adequate proportion of the rapidly increasing labour force largely due to poor timing and inadequate government commitment (GoK 1994; Swamy 1994).

A host of factors continued to constrain the country's export growth. First, the government was not only slow in implementing liberalization but also did little to put in place effective export promotion policies. Insufficient exchange rate adjustments in the 1980s frustrated import liberalization while inefficient fiscal adjustments worked against investment. The end result was a persistent bias against exports despite the announced shift away from import substitution to an outward-looking export strategy (Wignaraja and Ikiara 1999). High tariff rates and burdensome administrative procedures discouraged Kenyan exporters from vigorously pursuing export expansion programmes. Second, the government's institutional and administrative machinery continued to be biased in favour of import substitution, leading to slow and uneven implementation of export promotion policy reforms. Lastly, both the public and private sectors exhibited adverse attitudinal stances that worked against a successful push to increase manufacturing exports. Exporters frequently experienced difficulties in obtaining foreign exchange to facilitate trade promotion trips and other activities while their export compensation claims were delayed. The private sector, on its part, was often unwilling to take the steps necessary to raise competitiveness in international markets (KAM 1988).

In its quest to expand markets for its products, Kenya entered the Preferential Trade Area for Southern and East African countries in 1983 and ten years later joined the Common Market for Eastern and Southern Africa (COMESA). With the failure of SAPs to promote economic growth 
and improve people's welfare, the country renewed its momentum towards export promotion. In the 1989-96 plan period the government started restructuring the industrial sector using policy instruments expected to improve the efficiency and competitiveness of the sector and to re-orient it towards increased production for export and increased use of domestic resources. With increased liberalization of the domestic economy in the late 1980s and early 1990s, the government introduced further reforms to enhance the efficiency and competitiveness of manufacturing firms in both domestic and foreign markets. The objective was to promote industrial efficiency by switching to an outward-looking policy, central to which was the encouragement of an exportoriented manufacturing sector (GoK 1994).

In November 1991, donors froze their quick disbursing aid to Kenya as a result of the slow pace of economic and political reforms. This aggravated the country's economic crisis and balance of payments deficits and served as a critical catalyst for radical economic and political reforms soon after. By the end of 1991, the government had introduced Foreign Exchange Bearer Certificates (Forex-Cs), which became an important source of foreign exchange to the private sector. This marked an important first step in the liberalization of Kenya's foreign exchange market (Were et al. 2001). A secondary market for Forex-Cs was established in April 1992 and 100 per cent retention of foreign exchange earnings from the non-traditional exports such as manufactured goods and horticulture was allowed later in the year.

The institutional and market-oriented initiatives taken to re-orient the economy away from the import substitution strategy to export promotion included creation of a series of export platforms. Included among these was the Export Promotion Council established in 1993, the Export Compensation Scheme, Manufacturing Under Bond (MUB), export processing zones (EPZ), and import duty and value added tax remission schemes that were intended to improve export producers' access to imported inputs at world prices (Bigsten et al. 2010). These export platforms aimed to promote export-oriented manufacturing through a systematic process of tariff reductions and through a variety of market incentives, namely export promotion programmes. ${ }^{1}$ The Export Compensation Scheme was designed to compensate exporters for government taxes on inputs, while the MUB programme was meant to encourage manufacturing for world markets. Under the programme, which was open to local and foreign investors, inputs were imported duty-free. Tax reforms saw the tariff structure simplified through the reduction of the number of bands from eight in 1994 to five and the lowering of maximum ad valorem rates from 60 per cent in 1992 to 25 per cent in 1999 (Were and Kayizzi-Muregwa 2009). Furthermore, tariff bands were rationalized in order to eliminate misclassification, simplify tax administration, improve compliance, control smuggling and minimize exemption requests (Were and Kayizzi-Muregwa 2009). Other changes relevant to the manufacturing sector that were introduced included introduction of an Essential Goods Production Support Programme and abolition of price controls in 1994. In the 1993/94 budget, the government abolished the Export Compensation Scheme due to inherent problems in its implementation (Were and Kayizzi-Muregwa 2009). ${ }^{2}$

To attract foreign investors into the export sector, an Export Processing Act was passed in 1996 providing for the development of the Export Processing Zones Authority. However, the impact of the export promotion programmes on industrial exports has been limited partly owing to weaknesses in implementation and co-ordination.

\footnotetext{
${ }^{1}$ For a detailed description of the incentives, see Bigsten (2002: 17) and Gerdin (1997: 30ff.).

${ }^{2}$ It is opportunistic implementation of the Export Compensation Scheme that led to the hugely infamous Goldenburg scam.
} 


\subsection{New millennium policies}

Further relevant policy changes have occurred since the year 2000 that have had significant implications for industrial development and trade in Kenya. That year, the US government enacted AGOA that allowed African countries to export textiles and garments duty-free and without import quota restrictions. Kenya signed into AGOA soon after it was enacted, giving the EPZs a fresh push. The rise in exports of garments and apparel from Kenya from US $\$ 30$ million to US $\$ 249$ million between 2000 and 2005 has been attributed to export opportunities in the US fabric market. Kenya's export performance was further boosted by the revival of the EAC and greater participation by the country in the COMESA.

The Kenyan government's efforts to improve the sector's performance culminated in drafting the National Industrial Policy (NIP), finalized in 2007. The document takes stock of nonimplementation of industrial strategies outlined in Sessional Paper 2 of 1997. Lack of harmonized and coherent industrial policy hindered the implementation of the policies in the sessional paper. The NIP proposed creation of institutions to co-ordinate and facilitate industrial development with clear targets and benchmarks. Consequently, the National Industrial Development Commission (NIDC) was to be established for policy guidance and implementation. NIDC was to work closely with other institutions/forums like the private sector, the National Council for Micro, Small and Medium Enterprises, collaborating ministries, and universities and research institutions. The NIP identified 12 sub-sectors whose industrial policies were to be implemented within the framework of an Industrial Master Plan, the product of the Master Plan Study for Kenya's Industrial Development. However, by mid-2011, the NIP had not yet been launched. Prior to this, there had been growing awareness that generic policy approaches such as liberalization, stabilization and privatization were inadequate for the encouragement of widespread economic growth and development.

Policy reforms since 2000 have been spelt out in three blueprints, namely the Poverty Reduction Strategy Paper, the Economic Recovery for Wealth Creation, and Kenya Vision 2030. Contained in these documents are many proposals targeting the productivity and general performance of Kenyan industry (Bigsten et al. 2010). Under Vision 2030, the dream is to develop a diversified, robust and competitive manufacturing sector. This dream is to be realized through emphasis on local production, expansion in the regional markets, and identification of Kenya's niche in global markets (Republic of Kenya 2007). This means that Vision 2030 is preoccupied with external markets, and there is significant preoccupation with export-oriented strategies, and anticipation of a greater role for the manufacturing sector. For this reason, there have been fresh efforts to promote special economic zones and industrial parks, as well as industrial clusters. Of special focus under Vision 2030 is also the development of business process outsourcing, exploiting the country's rapid growth in the information communications and technology sector.

The building of a self-sustaining export-oriented industrial sector has been the central focus of the country's industrial development policy. Despite structural reforms undertaken, a close analysis of the manufacturing sector shows that supply responses to the policies have been poor. The average annual growth rate of real GDP for the manufacturing sector declined from 4.8 per cent in the period 1980-89 to 3 per cent and 1.3 per cent in the periods 1990-95 and 1996-2000, respectively. This was below the target of 7.5 per cent per annum for the period 1988-2000 (GoK 1986). The manufacturing sector in particular has been experiencing poor total factor productivity (TFP) growth rates that have been associated with sub-optimal plant sizes, under-utilization of installed capacities, low levels of investment, de-investment from the sector, limited technological advancement and uncompetitiveness in both domestic and foreign markets (Lundvall and Battese 1998; Lundvall, Ochoro and Hjalmarsson 2002). The failure of government efforts to achieve significant export volumes as per expectations has largely been blamed on government failure to 
appreciate that it needs to address other factors that hinder exports, such as inadequate infrastructure, increased crime, the spread of contraband and rising trade costs due to corruption (JICA and JBIC 2008).

While building on Vision 2030, there was renewed interest in industrial development in Kenya when the new Jubilee government came to power in March 2013. This is illustrated by the establishment of a Ministry of Industrialization charged with the responsibility for championing the country's industrial development. Other Jubilee government strategies/policies for promoting manufacturing are spelt out in its manifesto and include energy infrastructure and providing alternative ways to create adequate and more cost-effective energy supply (that is considered crucial for industrial take-off), reduce business taxation and unnecessary regulations and spur competition through enterprise zones and proposed new tax incentives to encourage manufacturing growth (Kenyatta et al. 2013).

\section{$3 \quad$ Key industrialization episodes and turning points}

Although Kenya's manufacturing enjoyed relatively rapid growth in the early post-independence years, it has generally been sluggish without dramatic shifts in performance. However, its performance has been shaped by some notable developments. The first of these is the carry forward of IS policies that were implemented during colonial rule and adopted by the independent government. IS policy served to ensure the availability of basic products in the domestic market. However, such products were overpriced and the policy distorted the evolution of industry by encouraging excess capacity and generalized inefficiency that undermined the ability of Kenyan products to penetrate external markets. A change came when the government eventually recognized the need to shift focus toward export promotion in the mid-1980s. However, immediate efforts to encourage exports were overshadowed by macroeconomic challenges and externally driven SAPs that were implemented half-heartedly and opportunistically.

The informal sector has existed for years but was officially recognized by the International Labour Office (ILO) in its 1972 report. This development led to not only a reduction in the harassment of informal firms by state organs but also the enactment of policies and administration interventions supportive of the sector. Since then, the informal sector has grown to become an important contributor to entrepreneurship, employment and creation of wealth (ILO 1972). Informal firms are ubiquitous in Kenya and provide a base for the country's private sector. Although often dismissed in most development literature, research has shown some growth and formalization opportunities for informal manufacturing firms in Kenya (Kimuyu 2010).

Liberalization of the Kenyan economy in the early 1990s through the dismantling of foreign exchange allocations and price controls was a turning point for the overall economy and industrial development. Although this policy created havoc for inefficient industries, those that survived were more able to participate in export markets. Manufacturers relying on imported material were better able to structure their import and production plans, keep to product export schedules and better pursue their entrepreneurial dreams.

Since publication of the Economic Recovery Strategy by the National Rainbow Coalition (NARC) government in 2004 and its successor Vision 2030, there has been more focus on improving the performance of the manufacturing sector. The period 2004-07 saw improved power supplies, increased supplies of agricultural products for agro-processing, tax reforms and tax incentives, more vigorous export promotion and liberal trade incentives that helped firms take advantage of the expanded market outlets. There was also a focus on improving the overall business climate including the rationalization of business licences. Enactment of the AGOA, revival of the EAC 
and deeper participation in COMESA opened up new opportunities for Kenyan capital and exports. Improvements in the investment climate in respective member countries made them attractive for Kenyan manufacturing firms who then set up operations in neighbouring countries. Kenya is currently the most important source of FDI in Uganda and Rwanda. The region, particularly Uganda, is the most important export destination for Kenyan products.

Table 1: Policies, institutions and laws enacted to promote industry in Kenya

\begin{tabular}{lll}
\hline Year & Policy/act/institution & Purpose \\
\hline 1954 & $\begin{array}{l}\text { Industrial and commercial } \\
\text { development corporation }\end{array}$ & $\begin{array}{l}\text { To increase industrial capability by encouraging participation of } \\
\text { indigenous Kenyans in industry and commerce. } \\
\text { To support import substitution industrialization. }\end{array}$ \\
1958 & $\begin{array}{l}\text { Protective tariff regime } \\
\text { Development Finance } \\
\text { Company of Kenya }\end{array}$ & $\begin{array}{l}\text { A government-owned investment company established to } \\
\text { promote post-independence industrialization. } \\
\text { To permit issuance to foreign-owned firms with a 'Certificate of } \\
\text { Approved Enterprise' allowing repatriation of profits, loans and } \\
\text { interest on loans as well as 'an approved proportion of the net } \\
\text { proceeds of sale of all or part of the approved enterprise'. } \\
\text { To secure specific types of trade and trading zones for retail and } \\
\text { wholesale for African businesses. }\end{array}$ \\
& Trade Licensing Act &
\end{tabular}

Kenya Industrial Estates

1968

1971

1973

1974

1979

$1981-82$

1983

1986

1990

1993-94

2000

2001
New Projects Committee

Capital Issues Committee

Industrial Development Bank

Export Compensation Manufacturer's Act

Kenya Bureau of Standards

Kenya Industrial Research Institute

Replacement of quantitative restrictions with equivalent tariffs, tariff reduction and rationalization

Establishment of the Investment Advisory Centre Manufacturing Under Bond

Investment Promotion Centre

Export processing zones Export Promotion Centre

\section{Export Programme Office}

Dismantling of import licensing and price control The American Africa Growth and Opportunities Act Kenya Industrial Property Institute
To encourage the entry of indigenous firms into manufacturing.

To serve as a bargaining forum between the government and multinational enterprises on investments.

To deal with all issues of capital stocks in order to stem potential capital flight occasioned by the threat of nationalization.

To advance industrial and overall economic development by promoting, establishing, expanding and modernizing medium and large-scale enterprises.

To promote export of non-traditional products under the import substitution industrialization strategy.

To promote the competitiveness of manufactured goods, both locally and internationally, by improving their quality.

To promote industrial innovation through the development of a sufficiently national capacity in embodied and disembodied industrial capabilities for self-sustaining industrialization.

To promote freer movement of manufactured goods.

To replace the 1968 New Projects Committee and attract FDI.

To promote exports.

To promote investment in Kenya and replace the Investment Advisory Centre.

To promote export-oriented industrial development. To formulate market strategies, promote an export culture and identify regional and global export opportunities.

A form of duty drawback scheme administered by the national treasury.

Liberalize the Kenyan market and make it more competitive and give Kenyan products a chance to compete in external markets. To promote the export of textiles from Africa to America.

To grant and enforce property rights and trademarks. 

mandatory investment thresholds and restrictive screening procedures for foreign investments. economic pillar on which Vision 2030 is founded pays special attention to manufacturing and proposes important flagship projects in support of the sector including development of integrated iron and steel mills that will lead to the local supply of machines and equipment.

Source: Modified from Kinyanjui (2013).

\section{The structure of the industrial sector}

\subsection{Sectoral composition}

Industrial activity, concentrated around the three largest urban centres-Nairobi, Mombasa and Kisumu - is dominated by food processing industries such as grain milling, beer production and sugarcane crushing, and the fabrication of consumer goods, such as vehicles from kits. Kenya also has an oil refinery that processes imported crude petroleum into petroleum products, mainly for the domestic market. A distinctive feature of the manufacturing sector in Kenya is the coexistence of the modern sector alongside a rapidly expanding informal sector. While the former comprises mainly small, medium and large enterprises, the informal sector consists of semi-organized, unregulated, small-scale activities that use low level technologies and employ few people. A large proportion of industrial output is directed towards satisfying basic needs, namely the provision of low-income consumer goods and services. Such items include clothing, furniture, foodstuffs and motor vehicle repairs. While data on this sub-sector are inadequate, it is one of the fastest-growing sectors and a major source of employment in Kenya.

The small and medium-scale enterprises, which form part of the formal economy, are characterized by some degree of specialization. These enterprises manufacture a wide range of items including wood and furniture, metal products, glass and pottery, clothing and leather products. The items are generally designed to meet the domestic needs of low-income households although some are exported to neighbouring countries.

The structure of Kenya's manufacturing sector has undergone minimal changes despite shifts in policies. Production is still largely geared towards consumer goods. Table 2 shows the share of total manufacturing (at the International Standard Industrial Classification three-digit level) value added by sectors from 2005 .

Table 2: Percentage share of total manufacturing value added by sub-sector

\begin{tabular}{llllll}
\hline Manufacturing activity (at current prices) & 2005 & 2006 & 2007 & 2008 & 2009 \\
\hline Manufacture of food products & 20.61 & 20.37 & 20.93 & 19.71 & 22.42 \\
Tobacco and beverages & 8.37 & 9.03 & 9.45 & 10.28 & 10.48 \\
Textiles & 1.87 & 1.80 & 1.73 & 1.51 & 1.19 \\
Clothing & 1.27 & 1.45 & 1.37 & 1.55 & 1.81 \\
Leather and footwear & 1.76 & 1.75 & 1.83 & 1.87 & 1.66 \\
Wood and cork products & 0.82 & 0.77 & 0.73 & 0.80 & 0.74 \\
Furniture & 0.78 & 0.74 & 0.79 & 0.95 & 1.01 \\
Paper and paper products & 4.42 & 3.98 & 3.92 & 5.27 & 3.15 \\
Printing and publishing & 2.86 & 2.52 & 2.58 & 1.89 & 2.42 \\
Industrial chemicals, paint and soap & 1.42 & 1.37 & 1.35 & 1.49 & 1.56
\end{tabular}




\begin{tabular}{llllll} 
Petroleum refineries & 15.87 & 15.43 & 15.37 & 9.54 & 4.75 \\
Rubber and plastic products & 3.29 & 3.27 & 3.02 & 2.62 & 2.83 \\
Other non-metallic mineral products & 11.72 & 12.54 & 12.92 & 16.94 & 19.42 \\
Metal products & 4.24 & 4.58 & 4.60 & 4.56 & 4.76 \\
Non-electrical machinery & 0.61 & 0.53 & 0.38 & 0.32 & 0.31 \\
Electrical machinery & 2.05 & 1.79 & 1.29 & 1.08 & 1.05 \\
Transport equipment & 1.50 & 1.76 & 1.61 & 1.72 & 1.74 \\
Miscellaneous manufacturing & 0.54 & 0.52 & 0.55 & 0.66 & 0.71 \\
Micro and small enterprises & 11.94 & 12.01 & 11.66 & 13.32 & 14.94 \\
Export processing zones & 4.05 & 3.79 & 3.93 & 3.90 & 3.07 \\
\hline
\end{tabular}

Source: KNBS (2006-10) and authors' calculations.

Although the manufacturing sector in Kenya is diversified in terms of manufacturing activities, processing of food and other agricultural goods still contributes the largest share of manufacturing GDP, followed by textiles and garments, and refining of crude petroleum, respectively. For instance, in 2006 the contribution of agro-processing of food commodities and refining of petroleum products to manufacturing value added to GDP was 21 per cent and 15 per cent, respectively. The single most important industrial sub-sector is food, beverages and tobacco, which forms over 30 per cent of total manufacturing output over recent years (Table 3). As indicated in the table, food manufacturing contributed about 22 per cent of manufacturing output, followed by other nonmetallic mineral products at about 19 per cent in 2009. The food, printing and publishing, rubber and plastic products and metal products sub-sectors recorded negative growth in 2008 but picked up in 2009. Growth theory suggests that nations tend to move from agrarian-led development towards manufacturing or technological development. Thus, the contribution of manufacturing would be expected to rise relative to that of agriculture. However, Kenya's manufacturing sector share of GDP is fairly stagnant, although the share of agriculture has itself declined. Nevertheless, significant complementary between the two sectors can be noted. Manufacturing output potential may lie in exploiting the value addition of agricultural products.

The manufacturing sector in Kenya is the third largest by sectoral contribution to GDP (10.3 per cent) after transport and communication (11.3 per cent) and agriculture and forestry (23.4 per cent) (KNBS 2008). The average annual growth rate of real GDP for the manufacturing sector declined from 10 per cent in the period 1974-79 to 4.8 per cent, 2.5 per cent and 3.8 per cent in the periods 1980-89, 1990-99 and 2000-07, respectively.

Table 3: Manufacturing value added (\% GDP)

\begin{tabular}{lcrrrr}
\hline & 2004 & 2005 & 2006 & 2007 & 2008 \\
\hline Brazil & 19.2 & 18.1 & 17.4 & 17.4 & 16 \\
China & 32.4 & 32.8 & 33.6 & 34.1 & 34.4 \\
Egypt, Arab Republic of & 18 & 17.3 & 16.6 & 15.7 & 16.9 \\
Botswana & 4.1 & 3.7 & 3.7 & 3.3 & 3.2 \\
Kenya & 11.3 & 11.8 & 11.6 & 11 & 9.1 \\
Mauritius & 21.1 & 20.2 & 19.1 & 19.9 & 19.4 \\
Malaysia & 30.4 & 29.6 & 29.6 & 28 &.. \\
Singapore & 27.5 & 26.9 & 26.9 & 24.9 & 20.8 \\
South Africa & 19 & 18.5 & 18.4 & 18.1 & 18.5 \\
Uganda & 7.6 & 7.6 & 7.7 & 7.7 & 7.6 \\
Tanzania & 7 & 6.8 & 6.9 &.. &.. \\
Korea, Republic of & 27.7 & 27.5 & 27.1 & 27.3 & 28.1 \\
\hline
\end{tabular}

Source: World Bank (2011). 
The manufacturing sector's share of GDP has increased only marginally in the last three decades, contributing only 10 per cent in the 1964-1973 period and 13.6 per cent in the 1990-1995 period. It reverted back to 10 per cent and stagnated at that level for most of the past decade. A combination of factors, including the import substitution strategy, poor weather conditions, import liberalization and deteriorating infrastructure could explain the slack. Although there has been a slight upswing in more recent years, the contribution of manufacturing to GDP has remained low; contributing 11.5 per cent and 12.8 per cent in the second quarters of 2009 and 2010, respectively. The manufacturing sector in general suffers from low value added compared to Malaysia, Singapore, Mauritius and South Africa but is higher than that of Uganda and Tanzania (Table 3).

\subsection{Manufacturing employment}

Kenya's manufacturing sector has been the main conduit for the country's integration into regional and world markets. The sector is a major source of employment in urban areas and possesses substantial backward and forward linkages to the rest of the economy. It is critical in achieving the country's vision of becoming prosperous and globally competitive by 2030 . Available data show that there has been substantial actualization of employment-casual employment as a proportion of total formal sector employment shows a marked rise since 1994. Informal and precarious forms of employment have gained momentum, as the system evolves towards employment of a diverse pool of irregular, flexible or casual workers with no formal labour contracts and employment benefits. ${ }^{3}$ Most of these employment effects have been witnessed during the period of intense trade liberalization and openness. This may have been largely undertaken as a cost-cutting strategy as casual workers usually do not enjoy fringe benefits or other employment benefits such as severance pay, medical allowances, and so on. The proportion of part-time and casual workers increased to 36 per cent in 2003 from 28 per cent in 1993. With increased competition, global trends show that firms seem to be using different forms of workforce flexibility as adjustment strategies. Note, however, that using Regional Programme on Enterprise Development data, similar firms to those tracked indicated that the number of employees reduced by 11 per cent between 1992 and 2002.

Employment growth averaged 1.43 per cent per annum over the 2005-09 period. The average annual growth rate declined from 3.34 per cent in 2007 to -0.75 per cent in 2008 . This was followed by a growth rate of 0.44 per cent in 2009 . Employment growth seems to have largely followed the decline in manufacturing output growth and hence economic growth. The increase between 2008 and 2009 could probably be due to an increase in the number of employees rather than an increase in the number of establishments, since the number of establishments declined during this period (see Table 6 under size distribution). The informal sector in manufacturing employed 1.8 million people in 2010, up from 1.7 million in 2009, an increase of 5.3 per cent.

The food, beverage and tobacco sub-sector was significantly affected by post-election violence and dry weather in 2009 . While the food, beverages and tobacco manufacturing sub-sector actually recorded negative growth in 2008-09, the performance of other manufacturing was not only positive but increased in 2008. This may be a pointer to low linkages between the two sub-sectors, meaning that the two sub-sectors neither support nor reinforce each other.

3 In the literature, such forms of employment are also referred to as 'non-standard forms of employment' or 'precarious employment'. Part-time workers in the context of this paper work under similar conditions as casual workers but for relatively shorter periods (three months or less). In both cases, payment is often at the end of the day or week or is piece-rate. 
The share of employment in manufacturing in Kenya was only 13.5 per cent (2006-07) ${ }^{4}$ whereas in China it was 31 per cent (2004-05) and in Malaysia it was 50 per cent over the same time period. If the Kenyan manufacturing sector is to perform along the lines of China and other East Asian countries, its share of both GDP and employment has to increase substantially. Table 4 shows the trends in percentage share of employment by sector.

Table 4: Trends in percentage share of employment by sector

\begin{tabular}{lrrrrr}
\hline Manufacturing activity & 2005 & 2006 & 2007 & 2008 & 2009 \\
\hline Manufacture of food products & 31.37 & 31.16 & 30.73 & 30.68 & 30.89 \\
Tobacco and beverages & 3.09 & 2.95 & 3.34 & 3.31 & 3.36 \\
Textiles & 17.59 & 17.73 & 17.49 & 17.59 & 17.12 \\
Clothing & 6.41 & 6.26 & 6.11 & 5.61 & 5.61 \\
Leather and footwear & 0.77 & 0.72 & 0.67 & 1.14 & 1.01 \\
Wood and cork products & 3.93 & 3.83 & 3.70 & 3.70 & 3.78 \\
Furniture & 1.78 & 1.75 & 1.71 & 1.64 & 1.69 \\
Paper and paper products & 3.38 & 3.33 & 3.25 & 3.28 & 3.34 \\
Printing and publishing & 3.46 & 3.48 & 3.45 & 3.34 & 3.32 \\
Industrial chemicals, paint and soap & 6.04 & 6.03 & 6.02 & 5.75 & 5.84 \\
Petroleum refineries & 0.10 & 0.09 & 0.08 & 0.09 & 0.10 \\
Rubber and plastic products & 4.24 & 4.49 & 4.80 & 4.71 & 4.64 \\
Other non-metallic mineral products & 3.14 & 3.39 & 3.80 & 3.99 & 4.08 \\
Metal products & 4.36 & 4.31 & 4.40 & 4.45 & 4.51 \\
Fabricated metal products & 3.50 & 3.44 & 3.36 & 3.28 & 3.35 \\
Non-electrical machinery & 0.61 & 0.59 & 0.58 & 0.60 & 0.62 \\
Electrical machinery & 1.23 & 1.19 & 1.15 & 1.15 & 1.14 \\
Transport equipment & 2.75 & 2.58 & 2.39 & 2.96 & 2.92 \\
Medical precision and optical instruments & 0.15 & 0.15 & 0.15 & 0.15 & 0.16 \\
Other manufacturing & 2.11 & 2.51 & 2.80 & 2.56 & 2.52 \\
Percentage employment growth & 1.6 & 2.52 & 3.34 & -0.75 & 0.44 \\
\hline
\end{tabular}

Source: KNBS (2006-10) and authors' calculations.

Table 3 reveals notable differences in terms of employment within the sub-sectors. Out of total wage employment in the manufacturing sector in 2009, food, beverages and tobacco contributed 34.25 per cent, whereas textiles and garments contributed 22.73 per cent. In 2009, the manufacturing sector contributed 13.27 per cent of total formal employment in Kenya. Note that, apart from the agriculture-based sub-sectors having a higher contribution to value added than all other manufacturing sub-sectors, these sub-sectors also absorb the largest shares (about 13 per cent) of manufacturing contribution to overall formal employment.

\footnotetext{
4 These values have been calculated from the number of employees by industry and employment groups reported in GoK (2008: 103ff).
} 


\subsection{Size distribution}

Table 5 shows the trends in distribution of employment by size. The firms are classified into micro enterprises (enterprises with ten workers or fewer), small-scale enterprises (11-50 workers), and medium and large enterprises (over 50 workers). ${ }^{5}$

Table 5: Percentage share in the distribution of employment by size/categories

\begin{tabular}{lcccc}
\hline Year/employees & $0-10$ & $11-50$ & $>50$ & \% growth \\
\hline 2005 & 1.65 & 9.89 & 88.46 & 1.60 \\
2006 & 1.65 & 9.88 & 88.47 & 2.52 \\
2007 & 3.42 & 25.70 & 70.88 & 3.34 \\
2008 & 3.28 & 25.22 & 71.50 & -0.75 \\
2009 & 3.29 & 25.01 & 71.70 & 0.44 \\
\hline
\end{tabular}

Source: KNBS (2006-10) and authors' calculations.

As shown in Table 4, the percentage share of employment across the years in the different size categories has been fluctuating, decreasing in 2008 probably due to post-election violence. The share has remained high in both medium and large enterprises over the years. The distribution in the sub-sectors indicates that food, beverages and tobacco had the highest percentage share of the total medium and large enterprises, while clothing, fabricated metal products, furniture, industrial chemicals, paint and soap and electrical machinery had the highest percentage share of total micro enterprises (see the Appendices). Table 6 shows the trends in number of establishments by size/categories.

Table 6: Percentage share in the number of establishments by size/categories

\begin{tabular}{lllll}
\hline Year/employees & $0-10$ & $11-50$ & $>50$ & \% growth \\
\hline 2005 & 32.62 & 34.24 & 33.17 & - \\
2006 & 32.94 & 34.16 & 32.878 & 0.82 \\
2007 & 32.92 & 34.21 & 32.875 & -0.73 \\
2008 & 32.98 & 34.25 & 32.775 & 1.68 \\
2009 & 32.96 & 34.25 & 32.782 & -0.02 \\
\hline
\end{tabular}

Source: KNBS (2006-10) and authors' calculations.

The percentage of manufacturing establishments across the three firm size categories is fairly stable and this proportion remained unchanged between 2005 and 2009. Given that over 70 per cent of industrial establishments consist of micro and small firms, the data therefore suggest that the proportion of formal manufacturing firms among small-scale establishments is relatively low. Similarly, the unchanging proportion of firms across firm size categories over the years is a pointer to a slow structural transformation process in the manufacturing sector in Kenya.

Interestingly, a decline in the number of employees in both micro and small enterprises is accompanied by an increase in the number of establishments, indicating new firm creation rather than increases in size in these categories. This implies a high level of 'churning' - that is, new

\footnotetext{
${ }^{5}$ Note that, due to data availability, the distribution in the World Bank survey disaggregates medium enterprises to comprise all firms with workers between 51 and 100 and large enterprises to comprise all firms with 101 workers or more.
} 
enterprises starting up and at the same time existing ones ceasing to operate. This is in contrast to the large enterprises where a decline in the number of employees is reflected in the decline in the number of establishments, and an increase in the number of employees is not reflected in the number of establishments, which would indicate that large enterprises absorb new employees into their existing enterprises.

\subsection{Ownership}

In Kenya, there are two ethnically distinct groups of businesses - those owned by Kenyans of Asian (largely Indian) origin and those owned by Kenyans of African origin. While the former constitute a small minority, their presence in trade and manufacturing is substantial (Himbara 1994). There might be extensive information flows amongst Kenyan-Asian entrepreneurs. For example, the formal or organized sector is relatively small with correspondingly few players, most of whom are Kenyan-Asians. In addition, for various political and historical reasons, this immigrant entrepreneurial community is socially embedded. For example, its members tend to live in clusters of close proximity, have social clubs that are vigorously participated in, and have numerous community activities both within and outside these clubs.

With regard to ownership and management of firms in Kenya's manufacturing industry, there have been significant changes since independence. Currently, multinationals and parastatals dominate the large industries while Kenyans of African origin dominate the micro and small ones. Table 7 shows enterprise ownership by ethnic origin.

Table 7: Enterprise ownership by ethnic origin

\begin{tabular}{|c|c|c|c|c|c|c|c|c|c|c|c|c|c|c|}
\hline & \multicolumn{2}{|c|}{ African } & \multicolumn{2}{|c|}{ Indian (Asian) } & \multicolumn{2}{|c|}{$\begin{array}{l}\text { Middle } \\
\text { Eastern }\end{array}$} & \multicolumn{2}{|c|}{ Other Asian } & \multicolumn{2}{|c|}{ European } & \multicolumn{2}{|c|}{ Other } & \multicolumn{2}{|c|}{ Total } \\
\hline & No. & $\%$ & No. & $\%$ & No. & $\%$ & No. & No. & $\%$ & No. & $\%$ & No. & $\%$ & No. \\
\hline Micro & 282 & 87.31 & 31 & 9.60 & 0 & 0.00 & 7 & 2.17 & 1 & 0.31 & 2 & 0.62 & 323 & 41.36 \\
\hline Small & 134 & 54.47 & 94 & 38.21 & 4 & 1.63 & 6 & 2.44 & 6 & 2.44 & 2 & 0.81 & 246 & 31.50 \\
\hline Medium & 20 & 22.47 & 49 & 55.06 & 1 & 1.12 & 6 & 6.74 & 9 & 10.11 & 4 & 4.49 & 89 & 11.40 \\
\hline Large & 14 & 11.38 & 76 & 61.79 & 5 & 4.07 & 15 & 12.20 & 10 & 8.13 & 3 & 2.44 & 123 & 15.75 \\
\hline Total & 450 & 57.62 & 250 & 32.01 & 10 & 1.28 & 34 & 4.35 & 26 & 3.33 & 11 & 1.41 & 781 & 100 \\
\hline
\end{tabular}

Source: Computed from World Bank (2007).

Most of the micro and small-scale enterprises are owned by Kenyans of African origin (Table 7). The share of African-owned businesses falls sharply as that of Indian origin and other Asian origin ownership increases up the enterprise size scale. As a consequence, Asians own a majority of the medium and large-scale enterprises, a finding consistent with Ikiara et al. (2002). Europeans and entrepreneurs from the Middle East own only a small proportion of all size categories compared to other entrepreneurs. The concentration of African entrepreneurs in micro and small businesses could be explained by African limited ability to mobilize financial and human resources (Ikiara et al. 2002).

Table 8 shows the legal status of firms by size category. 
Table 8: Legal status of firms by size category

\begin{tabular}{lllllllllllll}
\hline & \multicolumn{9}{c}{ Publicly listed } & \multicolumn{2}{l}{ Private Ltd. } & \multicolumn{2}{l}{$\begin{array}{l}\text { Sole } \\
\text { Proprietors }\end{array}$} & Partnership & Other & \multicolumn{3}{c}{ Total } \\
\hline & No. & $\%$ & No. & $\%$ & No. & $\%$ & No. & $\%$ & No. & $\%$ & No. & $\%$ \\
Micro & 0 & 0 & 51 & 14.13 & 213 & 72.69 & 64 & 55.17 & 0 & 0 & 328 & 42 \\
Small & 1 & 14.28 & 125 & 34.63 & 70 & 23.89 & 46 & 39.66 & 3 & 75 & 245 & 31.37 \\
Medium & 2 & 28.57 & 74 & 20.5 & 4 & 1.37 & 5 & 4.31 & 0 & 0 & 85 & 10.88 \\
Large & 4 & 57.14 & 11 & 3.05 & 6 & 2.05 & 1 & 0.86 & 1 & 25 & 23 & 2.95 \\
Total & 7 & 0.9 & 361 & 46 & 293 & 37.5 & 116 & 14.9 & 4 & 0.5 & 781 & 781 \\
\hline
\end{tabular}

Source: Computed from World Bank (2007).

Most micro firms were owned by sole proprietors, with the ownership declining with size category. Although the publicly listed companies' ownership was small across all the size categories, they still held the largest percentage share in the large size category. Private limited companies held the highest percentage share of small enterprises. About 94 per cent of the African-owned firms were sole proprietorship compared to 5.34 per cent of Indian-owned firms (Table 9).

Table 9: Legal status of firms by ethnic origin

\begin{tabular}{llllllllllllllll}
\hline & \multicolumn{1}{l}{ African } & \multicolumn{4}{l}{ Indian (Asian) } & \multicolumn{2}{l}{$\begin{array}{l}\text { Middle } \\
\text { Eastern }\end{array}$} & \multicolumn{2}{l}{ Other Asian } & European & Other & Total \\
\hline & No. & $\%$ & No. & $\%$ & No. & $\%$ & No. & $\%$ & No. & $\%$ & No. & $\%$ & No. & $\%$ \\
Public & 0 & 0.00 & 6 & 37.50 & 1 & 6.25 & 3 & 18.75 & 4 & 25.00 & 2 & 12.50 & 16 & 2.05 \\
$\begin{array}{l}\text { Private } \\
\text { Sole }\end{array}$ & 96 & 25.33 & 219 & 57.78 & 9 & 2.37 & 26 & 6.86 & 22 & 5.80 & 7 & 1.85 & 379 & 48.53 \\
proprietor & 266 & 94.66 & 15 & 5.34 & 0 & 0.00 & 0 & 0.00 & 0 & 0.00 & 0 & 0.00 & 281 & 35.98 \\
Partnership & 82 & 78.10 & 23 & 21.90 & 0 & 0.00 & 0 & 0.00 & 0 & 0.00 & 0 & 0.00 & 105 & 13.44 \\
Total & 444 & 56.85 & 263 & 33.67 & 10 & 1.28 & 29 & 3.71 & 26 & 3.33 & 9 & 1.15 & 781 & 100 \\
\hline
\end{tabular}

Source: Computed from World Bank (2007).

Of the total publicly owned companies, Indians had the highest percentage share followed by Europeans while Africans had no share. African firms not only start and remain small but also retain the simpler sole proprietorship legal status.

With regard to ownership and management of firms in Kenyan manufacturing, there have been significant changes since independence. Currently, multinationals and parastatals dominate the large industries while Kenyans of Asian origin dominate the small and medium ones. Kenyans of African origin own mainly micro enterprises. Most positions, particularly for the low and the middle level cadres, have since been Kenyanized. Although the Kenyan government has been a major actor in manufacturing through a number of parastatals, there has in recent years been a rolling back of public investment in line with the SAPs instigated by the IMF/World Bank. About half of the investment in the industrial sector is foreign, with the UK providing half of that. The USA is the second largest investor.

\section{$5 \quad$ Sunrise and sunset industries}

As highlighted in first section, the industrialization process in Kenya was, in the early postindependence period, clustered around three sub-sectors, namely textiles, food processing and metal industries. While the market liberalization policies of the 1980s led to collapse of the textile industry, food processing and metal industries have withstood the vagaries of a changing macro and policy environment and have developed over time, albeit slowly. AGOA in 2001 slightly changed the growth fortunes for the textile industry with exports of garments and apparel from Kenya increasing from US $\$ 30$ million in 2000 to approximately US $\$ 250$ million by 2005 (KIPPRA 2009). 
The growth in food processing and metal industries has largely been driven by expanding local and regional markets. However, growth in these sub-sectors was at its lowest ebb in 1990-2002 as the cost of doing business worsened then, occasioned by the near collapse of infrastructure, declining local demand and lack of clear policy direction.

Failure to create backward linkages to fully exploit the AGOA initiative, particularly in terms of reviving the cotton industry, delayed the envisioned growth in the textile industry. Increasing input costs and a lack of co-ordination in cotton marketing have been a disincentive to the cotton farmers. Similarly, the local textile products are not competitive enough to penetrate the local market, which has largely become the domain of textile imports. For instance, Kenya's textile industry has relatively high labour costs when compared to textile-producing countries like China and India.

The Economic Recovery Strategy (ERS) 2003-07 stressed the need to revitalize infrastructure and was categorical on the direction the government wanted industry to go. Further, enhanced discourse between the government and the private sector, particularly through the Kenya Association of Manufacturers, has been catalytic in raising government interest in addressing problems facing manufacturers. Indeed, the government is increasingly involving the private sector in the budget process as well as in decision-making on priority areas of the business environment.

Beyond textiles, food processing and metal industries, Kenya has diversified her manufacturing activities. Refining petroleum products, rubber and plastics manufacturing, paper and printing have increasingly contributed to manufacturing GDP. Similarly, manufacture of construction products, particularly cement, has had phenomenal growth, fuelled by increased demand from the real estate industry. This growth is expected to continue given the many infrastructure projects planned under Vision 2030 and general growth in the real estate and construction sectors. The steel and oil industry and other industries that feed on iron ore and petroleum products such as plastics are poised to grow phenomenally given recent discoveries of fossil resources and iron ore in Kenya.

\section{Labour and total factor productivity}

\subsection{Productivity and competitiveness}

Given the increasing openness of many economies, discussions about how competitive a country is, are of special importance because a globalized market environment demands that products compete locally with imports while at the same time trying to have a competitive edge in world markets. A country or a firm can either be price- or quality-competitive in specific products. Productivity is important for competitiveness. Firms that are not productive have a poor chance of competing for domestic and export markets. This is particularly so considering recent developments in which countries have opened their economies by dismantling trade barriers and enacting policies for promoting trade. Not only does productivity performance have a bearing on competitiveness, it also has a bearing on profits and wages, and ultimately poverty reduction and overall welfare. Productivity growth permits sustained economic expansion, greater demand for labour and increased real wages.

Two broad categories of factors determine competitiveness (Onjala 2002; Urata 1994). One category includes factors defining the operating environment, which is therefore exogenous to a firm. Competitive pressure, indicated by market concentration and openness of an economy buttressed in trade policies, are examples of such factors. In an acutely competitive environment, firms either match up regarding efficient use of factors of production or are forced out of the 
market purely as a response to external forces. The other category of factors includes those associated with the internal capability of firms. Such factors include managerial talent, reward systems, value-cost ratios and technological fitness. An analysis of firm level productivity is important in understanding the extent of preparedness of Kenyan manufacturers to compete in external markets. In this section, we attempt to assess the productivity of Kenya's manufacturing sector by exploring output per worker and TFP. Parametric measures of productivity are sensitive to the models used. For that reason, results obtained from this level of our analysis need to be viewed as indicative only.

In order to generate estimates on output per worker and firm level TFP, we use the 2007 World Bank datasets on manufacturing. These datasets collected information on the value of sales (used in this report to proxy for output), expenditure on equipment and building (used to proxy for capital), wage bill (used to represent labour input), and cost of raw materials. For growth in TFP in manufacturing, we need time series information on aggregate manufacturing output, capital and labour. The official statistical reports, such as the Statistical Abstract and Economic Survey, publish sufficiently disaggregated data on these variables. We were able to build a 1964-2010 series from these sources from which we applied a lag operator to generate the necessary changes in the variables in our estimation.

While it is quite easy to directly obtain information on the value of manufacturing output and the manufacturing wage bill, capital is always difficult to measure. This is because it is the flow of capital services rather than the actual capital stock that is needed to model productivity. However, such flow is difficult to track through time since it contains components such as dividends and interest charges that are not usually recorded on an annual basis. To circumvent this problem, the practice is normally to assume that capital services are proportional to the capital stock. In addition, we use fixed capital formation in the manufacturing sector as a proxy for flow of capital services. ${ }^{6}$ Information on the manufacturing sector's contribution to GDP and the aggregate manufacturing wage bill is also extracted directly from official statistical publications. Due to these data problems, our estimated productivity measures have to be treated as first approximations.

\subsection{Results of the productivity analysis}

Using official statistics on value added and employment, only available for firms with more than 50 employees, Table 10 shows the value added per employee across the manufacturing sub-sectors.

Table 10: Value added per employee for large firms by sub-sector

\begin{tabular}{lrrrrr}
\hline & 2005 & 2006 & 2007 & \multicolumn{1}{c}{2008} & 2009 \\
\hline Manufacture of food products & 391.47 & 430.16 & 488.68 & 537.67 & 605.13 \\
Tobacco and beverages & 0.00 & 1644.15 & 2215.70 & 2243.86 & 2607.95 \\
Textiles & 68.43 & 66.70 & 69.96 & 66.00 & 57.61 \\
Clothing & 119.08 & 152.16 & 163.00 & 198.48 & 245.07 \\
Leather and footwear & 1386.46 & 1576.57 & 2297.91 & 936.21 & -3386.81 \\
Wood and cork products & 125.80 & 132.77 & 144.18 & 165.36 & 157.86 \\
Furniture & 150.35 & 168.94 & 279.64 & 432.32 & 453.98 \\
Paper and paper products & 787.12 & 778.84 & 794.10 & 1232.70 & 772.28 \\
Printing and publishing & 498.71 & 631.60 & 542.52 & 436.78 & 593.94 \\
Industrial chemicals, paint and soap & 1149.08 & 711.44 & 745.97 & 1396.31 & 1615.59 \\
Petroleum refineries & 1776.16 & 2093.70 & 1363.23 & 3164.45 & 1092.62 \\
Rubber and plastic products & 469.85 & 445.39 & 453.84 & 419.74 & 484.58 \\
\hline
\end{tabular}

\footnotetext{
${ }^{6}$ This use of a proxy means that our results are at best provisional.
} 


\begin{tabular}{lrrrrr}
\hline Other non-metallic mineral products & 2268.16 & 2411.08 & 2458.75 & 3276.05 & 3904.34 \\
Metal products & 324.90 & 369.12 & 421.71 & 435.79 & 481.36 \\
Non-electrical machinery & 635.14 & 560.13 & 616.74 & 449.09 & 460.04 \\
Electrical machinery & 993.95 & 871.61 & 714.75 & 701.01 & 736.81 \\
Transport equipment & 328.89 & 453.61 & 527.30 & 615.62 & 1510.14 \\
Other manufacturing & 233.08 & 228.43 & 123.77 & 197.44 & 215.81 \\
Manufacturing total & 463.17 & 556.48 & 574.90 & 741.29 & 708.72 \\
\hline
\end{tabular}

Source: Computed from KNBS (2010).

Leather and footwear, industrial chemicals, petroleum refineries, other non-metallic products and electrical machinery have the highest levels of labour productivity, more than twice as high as the levels in other sectors. Note that from the previous discussions, out of the total wage employment in manufacturing sector in 2009, food, beverages and tobacco and textiles and garments have the highest employment percentage share compared to other sub-sectors, an indication that labour productivity in these other sectors is very low.

We use the 2007 World Bank data on the manufacturing sector in Kenya to compute labour and TFP. Some attributes of the variables of interest are summarized in Table 11. The table shows that intermediate and raw materials used in Kenyan manufacturing account for more that 64 per cent of the total cost of production. Labour accounts for 28 per cent.

Table 11: Firm level summary statistics

\begin{tabular}{llllll}
\hline Variables & Obs & Means & Std Dev & Minimum & Maximum \\
\hline In of sales & 781 & 16.63374 & 2.51444 & 10.49127 & 25.2119 \\
In of capital & 638 & 12.90093 & 2.280883 & 6.907755 & 24.41215 \\
In of labour & 781 & 14.61446 & 2.197246 & 8.987197 & 21.75038 \\
In of intermediate materials & 645 & 15.72116 & 2.729117 & 9.392662 & 23.55648 \\
Cost share of capital & 646 & 0.0776404 & 0.1137519 & 0 & 0.941596 \\
Cost share of labour & 646 & 0.2819479 & 0.1867813 & 0.0117647 & 0.9084302 \\
Cost share of materials & 646 & 0.6404116 & 0.2182811 & 0 & 0.9827445 \\
Clothing & 781 & 0.1177977 & 0.322575 & 0 & 1 \\
Textiles & 781 & 0.0396972 & 0.1953614 & 0 & 1 \\
Machinery & 781 & 0.0115237 & 0.1067965 & 0 & 1 \\
Chemicals & 781 & 0.0358515 & 0.1860389 & 0 & 1 \\
Wood & 781 & 0.1754161 & 0.3805664 & 0 & 1 \\
Metals & 781 & 0.0524968 & 0.2231696 & 0 & 1 \\
Exporters & 781 & 0.2010243 & 0.401023 & 0 & 1 \\
Exporters to developed & 145 & 0.1724138 & 0.379049 & 0 & 1 \\
countries & & & & & \\
\hline
\end{tabular}

Source: World Bank (2007).

The wood sub-sector had the largest proportion of firms in the sample, accounting for 17.5 per cent, followed by clothing with approximately 12 per cent. About 20 per cent of the firms are exporters and 17 per cent export to the developed world.

The results on firm level labour and TFP are summarized in Tables 12-16. As indicated in Table 12 , productivity in the food sector is greater than in garments and other sectors. This is true for both labour productivity and TFP. The food sub-sector appears an outlier from a manufacturing sector labour productivity perspective. However, the distinction is less dramatic when TFP is taken into account, suggesting that there is more capital deepening in the food sector relative to other sectors in Kenya's manufacturing sector. Table 13 shows that there is some size factor in labour 
productivity, in the sense that such productivity is greater for medium and large firms relative to the small firms. However, firm size does not seem to matter in TFP.

Interacting these productivity measures with export participation (Table 14) produces mixed results. On the basis of the mean labour productivity measures, export participation is inversely correlated with labour productivity. This is true for general export destinations and developed country destinations. These findings are counter-intuitive and may well suggest problems in the data. The theoretical expectation is that exporting should lead to greater productivity because external markets are usually more exacting and put pressure on firms to increase productivity. This is what the median measures of labour productivity seem to suggest, although the differences between exporters and non-exporters are not pronounced. ${ }^{7}$

Table 15 shows that where firms are located has no obvious productivity implications, since there are no observable productivity differences between firms that are located in industrial and EPZs and those located elsewhere. However, the legal status of a firm affects its productivity (Table 16). For example, privately owned firms appear more productive on the basis of mean labour productivity. The pattern changes somewhat when medians are used so that the results are inconsistent. But it is unclear what would lead to these outcomes on legal status of firms, except that partnerships may lead to a pooling of entrepreneurial talent that makes it possible for firms to operate with a different productivity threshold.

What about the pattern of changes in manufacturing TFP? Results on relevant TFP measures generated using translog models in both logarithms and levels are summarized in Figures 1 and 2 . The two figures reveal major spikes in changes in TFP in the early 1980s, mid-1990s and early 2000s, with the spikes for mid-1990 being highest relative to others. These are followed by inverted spikes in the mid-1970s, late 1980s/early 1990s and mid-1990s. The figures show that the change in manufacturing productivity reached rock bottom during the mid-1970s.

Table 12: Labour and total factor productivity by sector

\begin{tabular}{lcllc}
\hline Sector & \multicolumn{2}{c}{ Labour productivity } & \multicolumn{2}{c}{ Total factor productivity } \\
& Mean & Median & Mean & Median \\
\hline Food & 15.08759 & 6.35 & 3.977334 & 2.884879 \\
Textiles & 11.0139 & 4.9375 & 4.137512 & 3.174387 \\
Machinery & 9.551155 & 5.0 & 4.449301 & 3.408503 \\
Chemicals & 11.54015 & 9.666667 & 4.571164 & 3.390186 \\
Wood & 7.501865 & 5.9709 & 3.903343 & 3.401853 \\
Metals & 11.08819 & 5.950501 & 3.87107 & 3.354149 \\
\hline
\end{tabular}

Source: World Bank (2007).

Table 13: Labour and total productivity by firm size

\begin{tabular}{lcccc}
\hline Firm Size & \multicolumn{2}{c}{ Labour productivity } & \multicolumn{2}{c}{ Total factor productivity } \\
& Mean & Median & Mean & Median \\
\hline Small & 12.66 & 6.33 & 3.905787 & 3.071588 \\
Medium & 72.765 & 7.236 & 4.127252 & 3.137954 \\
Large & 16.863 & 8.748 & 3.400185 & 2.907599 \\
Other & 7.135 & 4.234 & 3.651921 & 3.21156 \\
\hline
\end{tabular}

Source: World Bank (2007).

\footnotetext{
${ }^{7}$ We were unable to test for the significance of these differences at this stage.
} 
Table 14: Labour and total factor productivity by export participation

\begin{tabular}{lcccc}
\hline Export orientation & \multicolumn{2}{c}{ Labour productivity } & \multicolumn{2}{c}{ Total factor productivity } \\
& Mean & Median & Mean & Median \\
\hline Exporters & 14.5504 & 8.139535 & 3.634471 & 3.074606 \\
Non-exporters & 32.217 & 6.082576 & 3.8712 & 3.102629 \\
Exports to dev. countries & 17.178 & 6.37 & 3.380612 & 2.977382 \\
Does not export to dev. & 31.802 & 8.735 & 3.794325 & 3.183989 \\
countries & & & & \\
\hline
\end{tabular}

Source: World Bank (2007.)

Table 15: Labour and total factor productivity by legal status

\begin{tabular}{lcccc}
\hline Legal status & \multicolumn{2}{c}{ Labour productivity } & \multicolumn{2}{c}{ Total factor productivity } \\
& Mean & Median & Mean & Median \\
\hline Public & 9.833137 & 10.0 & 2.662862 & 2.470757 \\
Private & 49.47346 & 7.5 & 3.930501 & 3.007306 \\
Sole proprietorship & 10.15215 & 5.434783 & 3.930501 & 3.070756 \\
Partnership & 12.51716 & 5.828667 & 3.831856 & 3.21156 \\
Others & 8.119988 & 5.665508 & - & - \\
\hline
\end{tabular}

Source: World Bank (2007).

Figures 1: Changes in total factor productivity in Kenyan manufacturing in natural logarithms

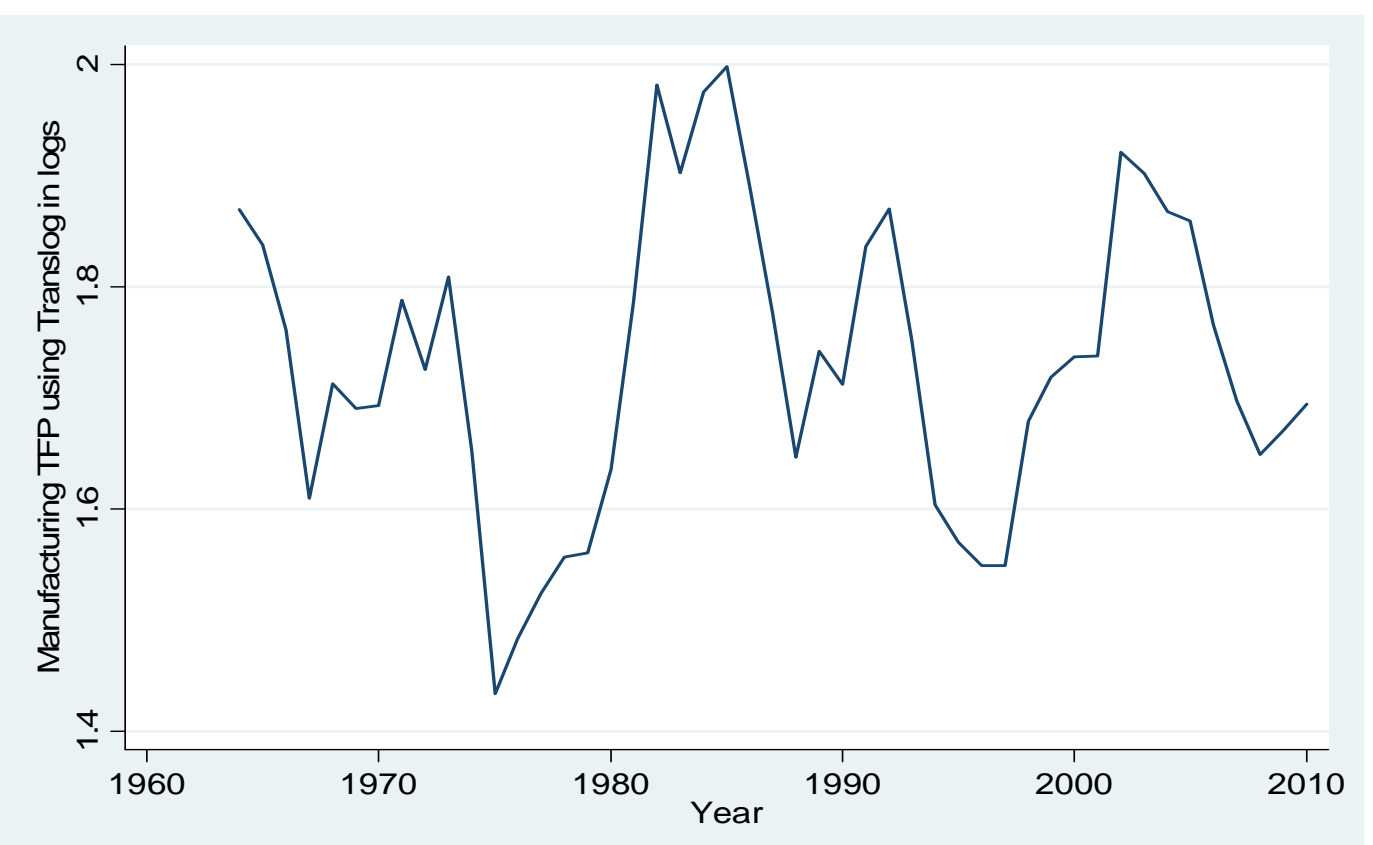

Source: World Bank (2007). 
Figures 2: Changes in total factor productivity in Kenyan manufacturing in levels

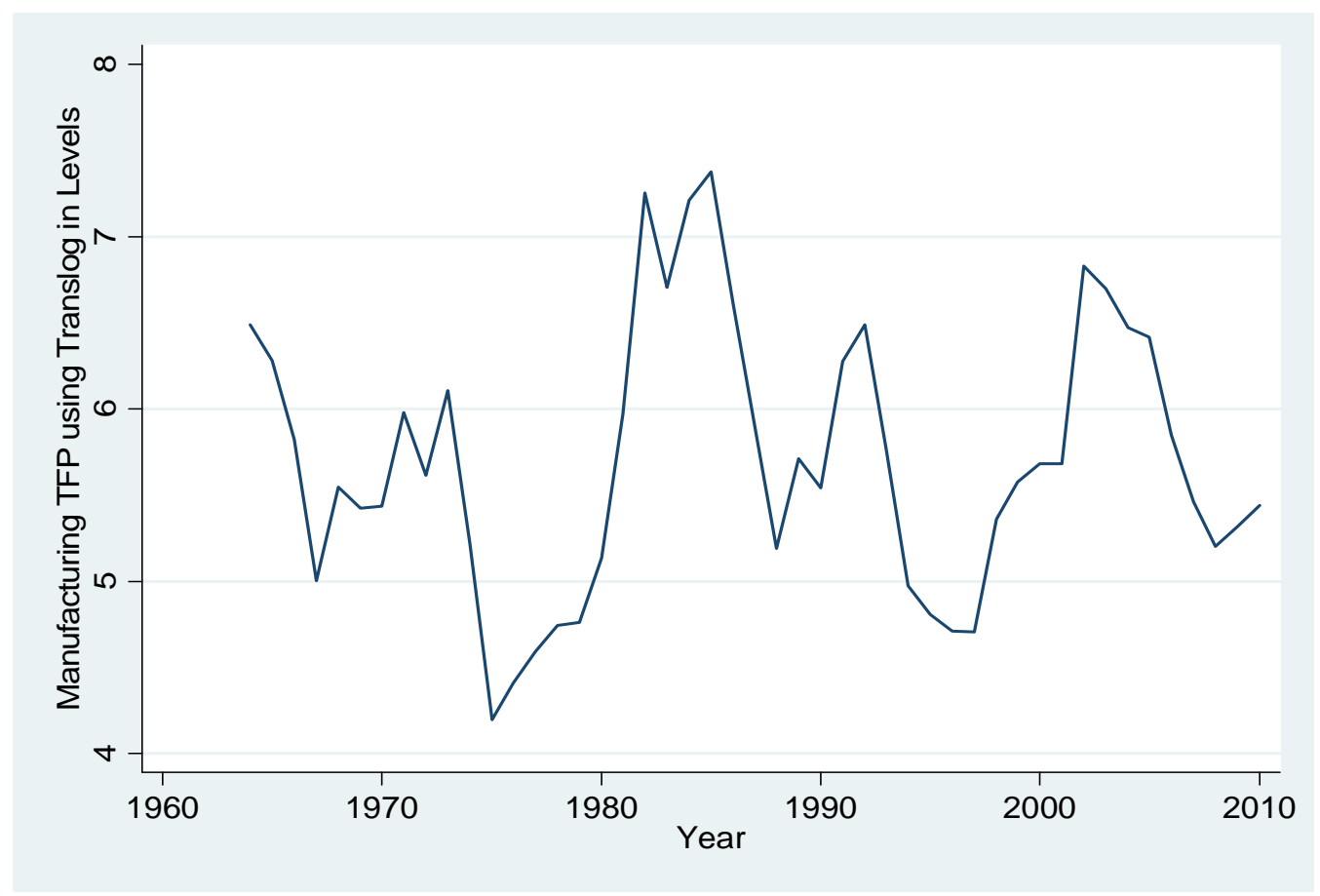

Source: World Bank (2007).

\section{$7 \quad$ Factors undermining industrial development in Kenya}

Industrial policies in Kenya have been less than consistent; as such policies have often been characterized by pendulum swings that are not helpful for steady industrial development. Even when the policy statements are potentially efficacious, stated policies have not always been diligently implemented. Failure to implement has often led to loss of industrial development opportunities. For example, the National Industrial Policy, which makes significant proposals, has yet to be implemented. While other countries have used the less technologically complicated textile sector to kick off rapid industrialization, Kenya allowed marketing boards to destroy the cotton value chain, beginning with the destruction of cotton growing and ginning. Major joint venture investments in cotton mills were unable to survive the lack of cotton and opportunistic management. State involvement in other agro-processing industries such as the sugar sector, dairy and meat processing, combined with the excesses of the co-operative movement to undermine what would have been huge industrial operations.

Many of the manufacturing enterprises are either micro or small in size. Studies have shown that firms in this size category face peculiar problems. First, they are under-capitalized and face very poor transformation prospects (Kimuyu 2010; Lundvall, Ochoro and Hjalmarsson 2002). Second, they have more limited access to financial services (Issakson and Wihlborg 2002). Most of their start-up and upgrading costs are funded through borrowing from family and friends (Green et al. 2007). As a result, they invest very little if at all, usually on used equipment (Söderbom 2002). Micro and small enterprises are less productive and less able to participate in external markets: studies have established a strong positive association between size and propensity to export (Graner and Issakson 2002). What all this means is that the dominance of small firms in Kenyan industry gets in the way of industrial development. 
Generally, Kenyan manufacturing has suffered poor productivity growth. There are numerous reasons for this outcome. Very little investment takes place, at firm and national level. The public sector emphasizes academic rather than technical education, which tends to have greater impact on overall productivity. Kenya does not have an adequate supply of infrastructure and many firms are forced to self-provide water, power and security. Firms are also not always able to focus on core business through lack of complementary services such as transport. Most firms end up spending resources on services that can be supplied more cost effectively through outsourcing.

Very little research and development takes place in Kenya. There are no mechanisms for linking industry with institutions of higher learning. The result is that there is neither obvious demand for nor beneficial application of results arising from research carried out by such institutions. 


\section{Appendix 1: A note on methodology}

We use simple measures of productivity interacted with firm size, sub-sector and export activity to analyse productivity in Kenyan manufacturing. There are two measures of productivity that are of interest here. One is labour productivity or simply output per worker. This measure is viewed as embodying the overall state of productivity performance (Issakson 2007). For that purpose, we measure labour productivity as a ratio of the value of total sales and expenditure on labour. In other words, we compute labour productivity using the formula

$$
\mathrm{LP}=\mathrm{Y} / \mathrm{W}
$$

where LP is labour productivity, $\mathrm{Y}$ is the value of output proxied by sales, and $\mathrm{W}$ is the wage bill at the firm level. Regarding the level of TFP, two methodologies are available, the first being a parametric one that starts with the estimation of a production function and extracts TFP thereafter. For example, we can first estimate the production function

$$
Y_{i}=\beta_{0}+\beta_{1} l_{i}+\beta_{2} k_{i}+\beta_{3} m_{i}+\varepsilon t
$$

where $\mathrm{Y}$ is as defined above, 1 is the wage bill, $\mathrm{k}$ is capital expenditure and $\mathrm{m}$ is expenditure on raw materials. All the variables are in their natural logarithms so that the production function has a simple Cobb-Douglas foundation. Subsequently, TFP can be recovered by netting out the estimated value of total production from the value of the actual production using the equation

$$
\mathrm{TFP}_{\mathrm{i}}=\mathrm{Y}_{\mathrm{i}}-\grave{\beta}_{\mathrm{l}} \mathrm{l}_{\mathrm{i}}-\grave{\beta}_{2} \mathrm{k}_{\mathrm{i}}-\grave{\beta}_{3} \mathrm{~m}_{\mathrm{i}}
$$

where $\grave{\beta}_{j}$ is the estimated coefficient for the factor $j$. Because this is in natural logarithm form, we can recover the corresponding levels by taking the exponentials of TFP obtained using the above formula. In other words, the level of the estimated TFP is given by $\exp \left(\mathrm{TFP}_{\mathrm{i}}\right)$. Alternatively, the more flexible translog form can be the basis for the estimations out of which the TFP can be recovered.

As argued in the literature, TFP estimates obtained using the parametric approach are very sensitive to the choice of production function and data type (Onjala 2002). Furthermore estimating TFP this way is fraught with many econometric problems: simultaneity or endogeneity due to potential correlation between productivity and input choices (Van Beveren 2007), assumptions about type of returns to scale, and inter-sector or inter-sub-sector heterogeneity (Issakson 2007). We circumvent these concerns by taking a simple non-parametric approach. ${ }^{8}$ This takes the form

$$
\mathrm{TFP}_{\mathrm{i}}=\mathrm{Y}_{\mathrm{i}}-\Sigma \mathrm{p}_{\mathrm{j}} \mathrm{X}_{\mathrm{j}}
$$

where $Y$ is total sales as defined above, $p_{j}$ is the share of total cost contributed by input $j$, and $x_{j}$ is the input of factor $j$. All the variables are in natural logarithms. Because this is in natural logarithm form, we can recover the corresponding levels by taking the exponentials of TFP obtained using the above formula. In other words, the level of the estimated TFP is extracted through exp $\left(\mathrm{TFP}_{\mathrm{i}}\right)^{9}{ }^{9}$

\footnotetext{
${ }^{8}$ See for example, Van Beveren (2007) for these concerns.

${ }^{9}$ Although we do not report the parametric TFP estimations, exploratory analysis using the World Bank datasets for 2007 showed that these estimates closely approximate the non-parametric estimates reported in this paper.
} 
We are also interested in the growth of TFP in the manufacturing sector. One way of doing this is to use time series data on the manufacturing sector, and exploit the notion of an aggregate production function. Regarding the specific functional form, one can use either the standard but restrictive Cobb-Douglas or the more flexible transcendental logarithmic form which also shows non-neutral technical change as well as quadratic growth. We use this latter form and compute TFP growth in two stages. First, we estimate a translog manufacturing aggregate production function as in Equation (5) below

$$
\operatorname{LnY}_{t}=\ln A_{t}+\beta_{k} \ln K_{t}+\beta_{l} \ln L_{t}+\beta_{k k} \ln K_{t}^{2}+\beta_{l l n} \ln t_{t}^{2}+\beta_{l k} \ln K \ln L
$$

TFP growth based on the translog is then computed using Equation (6) below

$$
\Delta \ln A_{t}=\Delta L_{n} Y_{t}-\beta_{k} \Delta \ln K_{t}-\beta_{l} \Delta \ln L_{t}-\beta_{k k} \Delta \ln K_{t}^{2}-\beta_{l l} \Delta \ln L_{t}^{2}-2 \beta_{l k} \Delta \ln K \Delta \ln L
$$

where $\Delta$ is the change between any two years. This equation is characteristic of growth accounting and can use factor shares estimated parametrically. ${ }^{10}$

\footnotetext{
${ }^{10}$ The Cobb-Douglas is a convenient if restrictive form of the production function, and is chosen in place of the more flexible translog form, and other non-parametric approaches that do not require restriction on income shares, with the intention of keeping the computation simple.
} 
Appendix 2: Percentage share in the distribution of employment by size/categories and sub-sectors

\begin{tabular}{|c|c|c|c|c|c|c|c|c|c|c|c|c|c|c|c|}
\hline $\begin{array}{l}\text { Manufacturing } \\
\text { activity/year }\end{array}$ & & 2005 & & & 2006 & & & 2007 & & & 2008 & & & 2009 & \\
\hline $\begin{array}{l}\text { Firm size } \\
\text { Manufacture of food }\end{array}$ & $0-10$ & $11-50$ & $>50$ & $0-10$ & $11-50$ & $>50$ & $0-10$ & $11-50$ & $>50$ & $0-10$ & $11-50$ & $>50$ & $0-10$ & $11-50$ & $>50$ \\
\hline products & 13.03 & 24.20 & 32.51 & 12.97 & 24.03 & 32.30 & 21.70 & 31.69 & 30.82 & 22.26 & 32.11 & 30.56 & 22.27 & 32.46 & 30.74 \\
\hline Tobacco and beverages & 0.00 & 0.33 & 3.46 & 0.00 & 0.32 & 3.30 & 0.04 & 1.30 & 4.24 & 0.00 & 1.45 & 4.12 & 0.00 & 1.49 & 4.17 \\
\hline Textiles & 1.05 & 4.28 & 19.39 & 1.05 & 4.20 & 19.55 & 1.73 & 3.88 & 23.18 & 1.90 & 4.00 & 23.11 & 1.88 & 4.03 & 22.39 \\
\hline Clothing & 35.43 & 18.07 & 4.56 & 34.76 & 17.68 & 4.46 & 27.10 & 9.48 & 3.88 & 25.96 & 8.87 & 3.53 & 25.86 & 8.94 & 3.52 \\
\hline Leather and footwear & 0.66 & 0.81 & 0.76 & 0.62 & 0.76 & 0.72 & 2.77 & 2.26 & 0.00 & 0.35 & 1.38 & 1.10 & 0.37 & 0.12 & 1.35 \\
\hline Wood and cork products & 7.23 & 6.67 & 3.57 & 7.06 & 6.49 & 3.47 & 1.85 & 6.53 & 2.76 & 1.92 & 6.65 & 2.74 & 1.95 & 6.85 & 2.79 \\
\hline Furniture & 6.82 & 5.22 & 1.30 & 6.72 & 5.15 & 1.28 & 5.86 & 2.96 & 1.06 & 5.86 & 2.89 & 1.00 & 6.02 & 3.00 & 1.03 \\
\hline Paper and paper products & 0.49 & 1.16 & 3.68 & 0.48 & 1.15 & 3.62 & 0.86 & 1.14 & 4.13 & 0.90 & 1.17 & 4.14 & 0.93 & 1.23 & 4.18 \\
\hline $\begin{array}{l}\text { Printing and publishing } \\
\text { Industrial chemicals, paint }\end{array}$ & 9.63 & 8.01 & 2.83 & 9.71 & 8.06 & 2.85 & 5.90 & 7.03 & 2.04 & 5.96 & 6.93 & 1.95 & 5.90 & 6.94 & 1.94 \\
\hline and soap & 6.57 & 7.32 & 5.89 & 6.53 & 7.29 & 5.88 & 4.56 & 8.61 & 5.16 & 4.74 & 8.27 & 4.90 & 4.83 & 8.42 & 4.98 \\
\hline Petroleum refineries & 0.00 & 0.00 & 0.11 & 0.00 & 0.00 & 0.10 & 0.00 & 0.00 & 0.12 & 0.00 & 0.00 & 0.13 & 0.00 & 0.00 & 0.14 \\
\hline $\begin{array}{l}\text { Rubber and plastic } \\
\text { products } \\
\text { Other non-metallic mineral }\end{array}$ & 1.10 & 2.51 & 4.49 & 1.15 & 2.66 & 4.75 & 2.89 & 5.23 & 4.74 & 2.94 & 5.22 & 4.61 & 2.88 & 5.18 & 4.53 \\
\hline products & 0.59 & 1.39 & 3.39 & 0.57 & 1.64 & 3.64 & 1.32 & 2.38 & 4.43 & 1.40 & 2.46 & 4.65 & 1.42 & 2.52 & 4.75 \\
\hline Metal products & 2.49 & 1.98 & 4.66 & 2.66 & 1.99 & 4.61 & 4.85 & 4.12 & 4.48 & 5.11 & 4.23 & 4.50 & 5.15 & 4.34 & 4.54 \\
\hline Fabricated metal products & 5.35 & 4.75 & 3.32 & 5.29 & 4.68 & 3.27 & 6.65 & 4.64 & 2.74 & 6.76 & 4.61 & 2.65 & 6.88 & 4.75 & 2.70 \\
\hline Non-electrical machinery & 0.00 & 1.29 & 0.54 & 0.00 & 1.26 & 0.53 & 0.00 & 1.46 & 0.28 & 0.00 & 1.56 & 0.30 & 0.00 & 1.60 & 0.30 \\
\hline Electrical machinery & 2.20 & 1.92 & 1.13 & 2.15 & 1.86 & 1.10 & 2.08 & 1.38 & 1.02 & 2.17 & 1.41 & 1.01 & 2.15 & 1.41 & 1.00 \\
\hline $\begin{array}{l}\text { Transport equipment } \\
\text { Medical precision and }\end{array}$ & 2.17 & 4.73 & 2.53 & 2.11 & 4.41 & 2.39 & 0.26 & 1.15 & 2.94 & 2.63 & 2.33 & 3.20 & 2.52 & 2.28 & 3.16 \\
\hline optical instruments & 0.00 & 0.00 & 0.17 & 0.00 & 0.00 & 0.17 & 0.13 & 0.22 & 0.13 & 0.14 & 0.22 & 0.13 & 0.15 & 0.23 & 0.14 \\
\hline Other manufacturing & 5.18 & 5.35 & 1.69 & 6.17 & 6.36 & 2.01 & 9.45 & 4.55 & 1.85 & 9.00 & 4.23 & 1.67 & 8.81 & 4.20 & 1.64 \\
\hline
\end{tabular}




\section{References}

Bigsten, A. (2002). 'History and Policy of Manufacturing in Kenya'. In A. Bigsten, and P. Kimuyu (eds), Structure and Performance of Manufacturing in Kenya. New York: Palgrave Macmillan.

Bigsten, A., Kimuyu, P., and Söderbom, M. (2010). 'The Manufacturing Sector'. In C. Adams, P. Collier, and N.S. Ndungu (eds), Kenya: Policies for Prosperity. Oxford: Oxford University Press.

Business Daily (2013). 'Busy Oil Exploration Places Kenya above its Neighbours'. 21 January 2013. Nairobi.

Chirwa, E.W. (2000). 'Structural Adjustment Programmes and Technical Efficiency in the Malawian Manufacturing Sector'. African Development Review, 12(1): 89-113.

Coughlin, P. (1988). 'Toward a New Industrialization Strategy in Kenya'. In P. Coughlin, and G.K. Ikiara (eds), Industrialization in Kenya: In Search of a Strategy. Nairobi: Heinemann.

Foroutan, F. (1993). 'Trade Reform in Ten Sub-Saharan African Countries: Achievements and Failures'. World Bank Policy Research Paper 1222. Washington, DC: World Bank.

Gerdin, A. (1997). 'On Productivity and Growth in Kenya, 1964-94'. Ekonomiska Studier 72. Doctoral Thesis. Gothenborg: Göteborg University.

Government of Kenya (GoK) (1994). 'Recovery and Sustainable Development to the Year 2010'. Sessional Paper 1: Nairobi: Government Printer.

GoK (1986). 'Economic Management for Renewed Growth'. Sessional Paper 1: Nairobi: Government Printer.

Graner, M., and A. Isaksson (2002). 'Export Performance'. In Bigsten, A. and P. Kimuyu (eds.), Structure and Performance of Manufacturing in Kenya. London: Palgrave Macmillan.

Green, C.J., Kimuyu, P., Manos, R., and Murinde, V. (2007). 'How do Small Firms in Developing Countries Raise Capital? Evidence from a Large Scale Survey of Kenyan Micro and SmallScale Enterprises'. In J. Hirschey, and A.K. Makhija (eds), Issues in Corporate Finance and Governance: Advances in Financial Economics Volume 2. New York-Oxford-Paris-San: Elsevier.

Hecox, W.E. (1988). 'Structural Adjustment, Donor Conditionality and Industrialisation in Kenya'. In P. Coughlin, and G.K. Ikiara (eds), Industrialization in Kenya: In Search of a Strategy. Nairobi: Heinemann.

Himbara, D. (1994). 'The Failed Africanization of Commerce and Industry in Kenya'. World Development, 22(3):469-82.

Ikiara, G.K., Kimuyu, P., Manundu, M., and Masai, W. (2002). 'Firm and Other Characteristics'. In A. Bigsten, and P. Kimuyu (eds), Structure and Performance of Manufacturing in Kenya. New York: Palgrave Macmillan.

International Labour Organization (ILO) (1972). 'Employment, Incomes and Equality: A Strategy for Increasing Productive Employment in Kenya'. Geneva: ILO.

Issakson, A. (2007). 'World Productivity Data Base: A Technical Description'. Staff Working Paper 10/2007. Vienna: Research and Statistics Branch, United Nations Industrial Development Programme.

Issakson, A., and Wihlborg, C. (2002). 'Financial Constraints on Kenyan Manufacturing'. In A. Bigsten, and P. Kimuyu (eds), Structure and Performance of Manufacturing in Kenya. New York: Palgrave Macmillan. 
Japan International Cooperation Agency and Japan Bank for International Cooperation (JICA and JBIC) (2008). 'Report of the Stocktaking Work on the Economic Development in Africa and the Asian Growth Experience'. Available at: jica-ri.jica.go.jp/IFIC_and_JBICIStudies/english/.../reports/.../aid_01.pdf (accessed 24 July 2014).

Kenya Association of Manufacturers (KAM) (1988). 'Rural Industrialization in Kenya: Opportunities and Constraints in Providing Basic Infrastructure'. Nairobi: KAM.

Kenyatta U., Ruto, W., Ngilu, C., and Balala Najibu (2013). ’Transforming Kenya: Securing Kenya's Prosperity 2013-2017'. Nairobi: Jubilee Coalition.

Kenya National Bureau of Statistics (KNBS) (2008). 'Economic Survey'. Nairobi: Government Printer.

KNBS (2010). 'Statistical Abstract'. Nairobi: Government Printer.

Kimuyu, P. (2010). 'Do Small Firms in Developing Countries Ever Transform?' Regional Development Studies, 14: 11-28.

Kinyanjui, B.K. (2013). Reversed Fortunes in the South: A Comparison of the Role of FDI in Industrial Development in Kenya and Malaysia. Leiden: African Studies Centre, University of Leiden.

Kenya Institute for Public Policy Research and Analysis (KIPPRA) (2009). 'Kenya Economic Report 2009: Building a Globally Competitive Economy'. Nairobi: Kenya Institute for Public Policy Research and Analysis.

Lundvall, K., and Battese, G.E. (1998). 'Firm Size, Age and Efficiency: Evidence from Kenyan Manufacturing Firms’. Working Paper 7/98. Armidale: Centre for Efficiency and Productivity Analysis, University of New England.

Lundvall, K., Ochoro, W., and Hjalmarsson, L. (2002). 'Productivity and Technical Efficiency'. In A. Bigsten, and P. Kimuyu (eds), Structure and Performance of Manufacturing in Kenya. New York: Palgrave Macmillan.

Ministry of Industrialization and Enterprise Development (2011). 'Kenya Seeks a Strategic Partner in Steel Mill Venture'. Business Daily. 24 March 2011.

Onjala, J. (2002). 'Total Factor Productivity in Kenya: The Links with Trade Policy'. AERC Research Paper 118. Nairobi: Africa Economic Research Consortium.

Republic of Kenya (2007). 'Kenya Vision 2030: A Globally Competitive and Prosperous Kenya'. Nairobi: Government Printer.

Söderbom, M. (2002). 'Investment Behaviour'. In A. Bigsten, and P. Kimuyu (eds), Structure and Performance of Manufacturing in Kenya. New York: Palgrave Macmillan.

Swamy, G. (1994). 'Kenya: Patchy, Intermittent Commitment'. In I. Husian, and R. Farugee (eds), Adjustment in Africa: Lessons from Country Case Studies. World Bank Regional and Sectoral Studies. Washington, DC: World Bank.

Urata, S. (1994). 'Trade Liberalization and Productivity Growth in Asia: Introduction and Major Findings'. The Developing Economies, XXXII(4): 363-72.

Van Beveren, I. (2007). 'Total Factor Productivity Estimation: A Practical Review', LICOS Discussion Papers 18207. Leuven, Belgium: LICOS - Centre for Institutions and Economic Performance.

Were, M., A. Geda, S.N. Karingi, and N.S. Ndung'u. (2001). 'Kenya's Exchange Rate Movement in a Liberalized Environment: An Empirical Analysis'. Discussion Paper 10. Nairobi: KIPPRA. 
Were, M., and Kayizzi-Muregwa, S. (2009). 'Do Exporting Firms Pay Higher Wages? Evidence from Kenya's Manufacturing Sector'. African Development Review, 21(3): 435-53.

Wignaraja, G., and G. Ikiara (1999). 'Adjustment, Technological Capabilities, and Enterprise Dynamics in Kenya'. In S. Lall (ed.), Opening Up, and Shutting Down? Import Liberalization and Industrial Technology in Sub-Saharan Africa. Oxford: Oxford University Press.

World Bank (2007). 'Investment Climate Assessment'. Washington, DC: World Bank.

World Bank (2011). 'World Development Indicators'. Washington, DC: World Bank. 